\title{
PEMENUHAN GIZI LEWAT KONSUMSI DAN JENIS TANGKAPAN IKAN DI DAERAH NELAYAN KODEOHA SULAWESI TENGGARA
}

\author{
Ivonne Siswanty ${ }^{1,2, *}$, Dewi Ratnasari ${ }^{3}$ \\ ${ }^{1}$ Balai Riset Perikanan Budidaya Air Payau dan Penyuluhan Perikanan, Maros Sulawesi Selatan \\ ${ }^{2}$ Dinas Perikanan dan Kelautan, Kolaka Sulawesi Tenggara \\ ${ }^{3}$ Politeknik Kesehatan Kementerian Kesehatan, Jalan Baji Gau No. 49, Makassar \\ *Corresponding author: Telp: +62811401613, email: ivonnesiswanty@ gmail.com
}

\begin{abstract}
ABSTRAK
Pemenuhan gizi lewat slogan "gemarikan" menjadi popular dan meningkatkan konsumsi ikan di Indonesia. Konsumsi ikan dari tahun ke tahun mengalami tren peningkatan, walaupun tidak terlalu tinggi di tahun 2017 sebesar 46,49 kilogram/kapita/tahun dan mencapai 55,95 kilogram/kapita/tahun di 2020 yang telah melewati pencapaian target nasional tahun 2019 yaitu 54,49 kilogram/perkapita/tahun. Hal ini memberikan kabar gembira bagi nelayan untuk memberikan tangkapan ikan yang lebih produksi dan segar. Untuk pembangunan masyarakat Indonesia, peningkatan konsumsi ikan diharapkan mampu meningkatkan asupan gizi masyarakat, dimana ikan merupakan bahan pangan yang mengandung protein berkualitas tinggi. Kodeoha merupakan salah satu kecamatan di Kabupaten Kolaka Utara Sulawesi Tenggara yang memiliki potensi sumberdaya perikanan. Penelitian ini bertujuan untuk mengetahui ketersediaan tangkapan ikan untuk pemenuhan gizi masyarakat di daerah nelayan Kodeoha, Kolaka Utara Sulawesi Tenggara. Temuan yang didapat selama satu bulan di daerah nelayan Peneliti menemukan berbagai jenis ikan yang ditangkap pada setiap perjalanan nelayan. Ikan Layang (Decapterus ruselli) tertangkap lebih banyak $(50,4 \%)$ dari semua ikan yang ditangkap, diikuti oleh ikan Baronang (Siganus limeatus) (12,9\%), ikan kembung lelaki (Rastrelliger sp) (9,7\%), ikan Peperek (Leiognatus sp) $(9,7 \%)$, ikan cendro (Thryssa hamiltonii) (11,3\%), dan ikan biji nangka (Tylerius spinosissimus) $(6,5 \%)$. Berbagai jenis tangkapan memberikan kandungan gizi yang bervariasi pula, dan diharapkan memicu minat masyarakat untuk mengkonsumsi ikan.
\end{abstract}

Kata Kunci: Pemenuhan Gizi, Konsumsi Ikan, Tangkapan Ikan

\section{ABSTRACT}

Nutritional fulfillment through the slogan "gemarikan" became popular, increasing fish consumption in Indonesia. Fish consumption has been increasing year after year, though it was not too high in 2017 at 46.49 kilograms/capita/year, and it reached 55.95 kilograms/capita/year in 2020, exceeding the 2019 national target of 54.49 kilograms/per capita/year. This is good news for fishermen because it means more productive and fresh fish catches. Increased fish consumption is expected to be able to increase the nutritional intake of the community, as fish is a food item that contains high-quality protein, for the development of the Indonesian people. Kodeoha is one of the sub-districts in North Kolaka Regency, Southeast Sulawesi, with fishery resource potential. The purpose of this study is to determine the availability of fish catches for community nutrition in the fishing area of Kodeoha, North Kolaka, Southeast Sulawesi. Findings Findings obtained in fishing areas over a month The researchers discovered a variety of fish caught on each fishing trip. Layang fish (Decapterus ruselli) accounted for the majority of all fish caught (50.4 percent), followed by Baronang fish (Siganus limeatus) (12.9 percent), male mackerel (Rastrelliger sp) (9.7 percent), Peperek 
fish (Leiognatus sp) (9.7 percent), cendro fish (Thryssa hamiltonii) (11.3 percent), and jackfruit seed fish (Tyle (6.5 percent). Various types of catch have varying nutritional content and are expected to pique the public's interest in eating fish.

Keywords: Nutritional Fulfillment, Fish Consumption, Fish Catch

\section{PENDAHULUAN}

Indonesia memiliki tingkat keragaman hayati tertinggi yaitu $37 \%$ total spesies ikan yang ada di dunia. ${ }^{1}$ Melihat kondisi geografis tersebut, lautan Indonesia kaya dengan sumber daya yang sangat besar untuk dieksploitasi. ${ }^{2}$ Sumber daya tersebut dapat berupa kekayaan alam seperti ikan, ${ }^{3}$ dan biota laut $^{4}$ yang diburu oleh para nelayan yang tinggal di pesisir pantai, salah satunya adalah nelayan Kodeoha. Kodeoha merupakan salah satu Kecamatan yang berada di Kabupaten Kolaka Utara Sulawesi Tenggara. Kabupaten Kolaka Utara mencakup wilayah daratan dan kepulauan yang memiliki daratan seluas $3.391 \mathrm{~km} 2$ dan wilayah perairan (laut) diperkirakan seluas $\pm 5000 \mathrm{~km}^{2}$. Secara geografis terletak memanjang dari utara ke selatan berada diantara $2.00^{\circ}$ Lintang Selatan dan membentang dari Barat ke Timur di antara $122.045^{\circ}-124.060^{\circ}$ Bujur Timur yang berbatasan dengan Kabupaten Luwu Timur (Sulawesi Selatan) di bagian utara, Kabupaten Kolaka (Sulawesi Tenggara) di bagian Timur dan Selatan, dan Teluk Bone di bagian Barat. Kecamatan Kodeoha yang beribukota di Mala-Mala berjarak $25 \mathrm{~km}$ dari kota Kabupaten, Lasusua. Kodeoha terdiri dari 11 desa dan 1 kelurahan. Penduduk masyarakat Kodeoha mayoritas bermatapencaharian sebagai nelayan untuk memenuhi hidup sehari-hari.

Menurut Dinas Kelautan dan Perikanan Provinsi Sulawesi Tenggara, konsumsi ikan di Sulawesi Tenggara tergolong tinggi mencapai 58,81 kilogram perkapita per tahun. Tingkat konsumsi tersebut merupakan urutan ketiga di Indonesia setelah Maluku dan Riau. ${ }^{5}$

\section{METODOLOGI}

Bahan yang digunakan dalam penelitian ini adalah lembar wawancara dan observasi, sedangkan alat yang digunakan adalah set gillnet, kamera, alat ukur (penggaris), tabulasi data, dan alat tulis menulis.

Penelitian ini menggunakan metode eksperimen, yaitu metode percobaan dengan cara menghitung hasil tangkapan nelayan langsung di lapangan. Penelitian ini dilakukan selama 1 bulan dengan pencatatan trip setiap hari (selama 31 trip).

\section{HASIL DAN PEMBAHASAN}

\section{Tangkapan tiap trip}

Hasil yang diperoleh pada pengoperasian alat tangkap set gillnet diperoleh hasil tangkapan ikan yang bervariasi sesuai dengan trip yang dilakukan. Jenis ikan yang tertangkap pada setiap trip digambarkan pada Gambar 1, yang menunjukkan ikan layang selalu muncul setiap trip dengan persentase $50 \%$. Sedangkan ikan cendro tertangkap pada trip ke: 1, 2, 8, 10, 15, 23, dan 26 dengan persentase $11.30 \%$. Ikan baronang tertangkap pada trip ke: $3,7,11,17,22,25,29$, dan 31 dengan persentase $9.70 \%$.

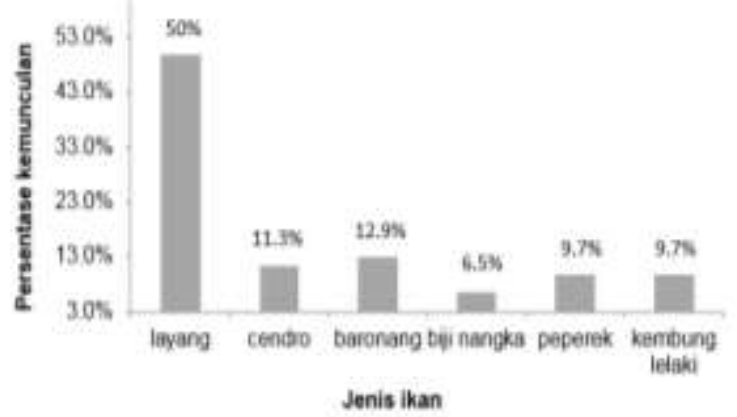

Gambar 1. Presentasi kemunculan jenis ikan tangkapan Nelayan Kodeoha

Sedangkan ikan biji nangka tertangkap pada trip ke: 4, 19, 20, dan 30 dengan memiliki persentase $6.49 \%$. Ikan Peperek tertangkap pada trip ke: $6,9,16,18,21$, dan 27 dengan persentase $9.70 \%$. Sedangkan ikan Kembung lelaki tertangkap pada trip ke: 5, $12,13,14,24$, dan 28, dengan persentase $9.70 \%$. 


\section{Jenis Tangkapan}

Selama penelitian, jenis-jenis ikan yang banyak tertangkap dengan set gillnet adalah ikan layang (Decapterus ruselli), baronang (Siganus limeatus), kembung lelaki (Rastellinger sp), peperek (Leiognatus sp), cendro (Thryssa hamiltonii, dan biji nangka (Tylerius spinosissimus), dengan persentase hasil tangkapan set gillnet selama penelitian di Kecamatan Kodeoha seperti yang diperlihatkan pada gambar 2 .

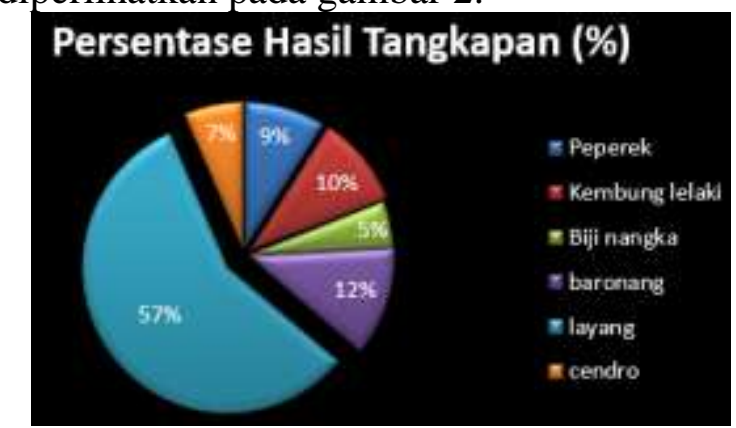

Gambar 2. Persentase jenis ikan hasil tangkapan Nelayan Kodeoha

Ikan Layang (Decapterus ruselli) merupakan salah satu sumber protein hewani yang sangat penting bagi kebutuhan hidup manusia (Yoesoef, 1974 dalam Genisa 1998). Bagi penduduk Indonesia kebutuhan akan protein dari hewani, khususnya ikan ini masih jauh dari mencukupi, ${ }^{6}$ oleh karena itu salah satu jalan untuk mengatasinya dengan mempertinggi hasil produksi perikanan. Dari hasil penelitian ini, ditemukan jenis ikan Layang paling sering tertangkap oleh set gillnet, hal ini dapat menguntungkan pihak nelayan yang dapat memenuhi protein keluarga para nelayan dan masyarakat disekitarnya.

\section{SIMPULAN DAN SARAN}

Beragam jenis ikan memberikan dampak gizi yang bervariasi sehingga asupan gizi dapat terpenuhi dengan baik. Selain itu, variasi jenis ikan memicu keinginan masyarakat untuk mengkonsumsi lebih banyak sesuai dengan rasa dan aroma ikan yang juga bervariasi.

\section{PERSANTUNAN}

Penulis mengucapkan terima kasih kepada Kepala Daerah Kolaka Utara, Camat dan masyarakat nelayan di Kodeoha atas pemberian izin untuk melaksanakan penelitian ini.

\section{DAFTAR PUSTAKA}

1. Kementerian Kelautan dan, Perikanan Republik Indonesia. Produktivitas Perikanan Indonesia. Published online 2018.

2. Kamaruddin M, Marzuki I, Burhan A, Ahmad R. Screening acetylcholinesterase inhibitors from marine-derived actinomycetes by simple chromatography. IOP Conf Ser: Earth Environ Sci. 2021;679(1):012011. doi:10.1088/1755-1315/679/1/012011

3. Marzuki I, Pratama I, Ismail HE, et al. The Identification and Distribution Components of Polycyclic Aromatic Hydrocarbon Contaminants at the Port of Paotere, Makassar, South Sulawesi. IOP Conf Ser: Earth Environ Sci. 2021;679(1):012017. doi:10.1088/1755$1315 / 679 / 1 / 012017$

4. Marzuki I, Kamaruddin M, Ahmad R. Identification of marine spongessymbiotic bacteria and their application in degrading polycyclic aromatic hydrocarbons. Biodiversitas. 2021;22(3). doi:10.13057/biodiv/d220352

5. Suparman. Tingkat Konsumsi Ikan Masyarakat Sultra Terttinggi Ketiga. Antara News. https://sultra.antaranews.com/berita/2967 60/tingkat-konsumsi-ikan-masyarakatsultra-tertinggi-ketiga. Published 13 Oktober.

6. Kamaruddin M, Karlina I, Nurhayani N. DESKRIPSI PENGETAHUAN DAN PEMAHAMAN MAHASISWA AKADEMI KEBIDANAN TAHIRAH 
MEDIKA ALKHAIRAAT : JURNAL PENELITIAN KEDOKTERAN DAN KESEHATAN 3(3):105-108 e-ISSN: 2656-7822, p-ISSN: 2657-179X

AL BAETI TENTANG ANEMIA IBU HAMIL. MAJPKK. 2019;1(3):103-107. doi:10.31970/ma.v2i3.62 